\title{
The Slovak Stories of Timrava and their English Translation
}

\author{
Peter Hála \\ University of Alberta, Canada
}

\section{History, Culture and Language of Slovakia}

Božena Slančíková (1867-1951), known by the pen name "Timrava", was a renowned Slovak writer. She was one of the few Czechoslovak artists who was awarded the prestigious title of "National Artist of Czechoslovakia". This paper focuses on the translation of Timrava's works into English, first undertaken by Norma L. Rudinsky, and expands the scope of Rudinsky's pivotal effort. ${ }^{1}$

Timrava lived in the southern part of Slovakia bordering Hungary where the influence of the Magyar language and culture was a strong social and cultural force, and her works cannot be understood without at least some rudimentary history of Slovakia and Slovak language. Historically and culturally, this is one of the most complex geographical areas in the world, and, with further study, it could serve as an excellent example for any trans-cultural and trans-historical translation. Unfortunately, an adequate unbiased analysis of Slovak history is still not easy to come by. ${ }^{2}$

The documented history of Slavs starts with the coming of the Slavic tribes who settled in Central Europe in the $5^{\text {th }}$ and $6^{\text {th }}$ centuries, in the lands previously occupied by the Celts, and other pagan tribes. These Slavs were originally converted to Christianity by Latin-speaking, Frank (French and German) and Irish missionaries. The apex of these Slavic tribes became the Great Moravia of King Svätopluk. After the invading Magyar tribes destroyed and occupied Great Moravia in 950 AD, for the next millennium these Slavs came under direct Magyar influence, especially in southern Slovakia. The remote mountainous parts of central and northern Slovakia, later also under Magyar influence, remained mostly inaccessible wilderness, allowing various Slovak dialects to survive in their more pure form. It is in this sense that modern Slovak is considered linguistically the closest of all Slavic languages to the original Old Slavonic, and that is also why the word Slovak/Slováci was considered the synonym for Slavs (Slovan, Slovanĕ, Slovania).

\footnotetext{
${ }^{1}$ An earlier version of this paper was presented at the $12^{\text {th }}$ St. Jerome's Day conference, on September 30th 2014 , at the University of Alberta, Edmonton, Canada. I would like thank Dr. Anne Malena, professor of French and Translation Studies at the University of Alberta, for an opportunity to present my thesis. I am also grateful to my colleague Mr. Kevin Beauchamp for wholeheartedly reviewing this paper and for his valuable comments and corrections.

${ }^{2}$ Various histories, from the first ones written during the Austro-Hungarian Empire era to those during the Communist era, are all biased, as they served various nationalistic and ideological purposes. One limited attempt to write an objective outline can be found in Hála.
} 
There has always existed a strong affinity between the Slovak and Czech languages. Originally there was only one proto-Slavic, the Old Slavonic, and the Slavic tribes which settled in Europe all spoke the same langauage. ${ }^{3}$

The words Magyar and Hungarian are interchangeable in English. Not much was left of the original Huns of Attila in the 9 $9^{\text {th }}$ century, but Hungarian seems to be preferred in English, as it denotes all these Ungur (Ogur) tribes of which the Magyars of Árpád were the leading tribe in the 9th century. The Czech word Uhry also denotes the more general Ungur connotation. The Slovak Mad'ar is more specific since it refers to the leading role of Magyars and their grand-prince Árpád who united the Ungur tribes and whose descendants, the Magyar Kings of the House of Árpád, founded Magyarország or the 'Magyar-country.' These Magyars (the united Ungurs) were converted to Christianity largely due to the efforts of the Czech missionary St. Vojtech (Adalbert) and became a part of the Western Latin Church.

Slovakia or Upper Hungary was repeatedly invaded and dominated by foreigners. The original Slavic or proto-Slovak inhabitants, whatever remained of them and their language, thus came under various cultural and linguistic influences. The devastating Mongol/Tatar invasion of Batu Khan in 1241 was followed in 1271 by the invasion of the Czech King Přemysl Ottokar II who ravaged key Slovak cultural centres. In 1285 the Tatars returned with brute force and the Turcic Cumans attacked western Slovakia. Between 1428 and 1433 the Hussites plundered Catholic Upper Hungary, creating a long-lasting antipathy of many Slovaks towards the Hussites and Czechs. This was followed by the invasion of Jan Jiskra from Brandýs, (battle of Lučenec in 1451), representing the alliance of the Czech King Ladislav Posthumous/Pohrobek and the Hungarian Queen Elizabeth.

After the battle of Mohács in 1526, where the Ottoman Turks defeated the Hungarian and Bohemian Christian army, Slovaks and their language came under Turkish influence. There are still words of Turkish origin in modern Slovak. In the north of Slovakia words of Polish origin were adopted. The Slovak dialect of eastern Slovakia resembles the Ruthenian and Ukrainian languages. In the $16^{\text {th }}$ century the Czech and German Protestant émigrés polarized Upper Hungary religiously and influenced the native language of Slovaks.

Ever since German (Eastern Frank) missionaries and merchants came to Great Moravia, the German influence was strong both in Bohemia and Slovakia. This influence was later strengthened when the Hungarian and Bohemian Kings from the $12^{\text {th }}$ to the $15^{\text {th }}$ centuries repeatedly invited skilled German miners and metallurgists to settle in their lands. The Slovak town of Banská Štiavnica in southern Slovakia was settled by German miners as early as the $12^{\text {th }}$ century and the German mining

\footnotetext{
${ }^{3}$ This allowed saints Cyril and Methodius to devise one Slavonic script in the $9^{\text {th }}$ century. Several hundred of their followers expelled from Great Moravia in 884 by King Svätopluk were still able to fully communicate with the Slavic tribes in Bohemia, Poland, and in the Balkans.
} 
prospectors were invited also to the nearby town of Lučenec (Luchunch) in 1275 to further explore the Terra Losunch region for gold and silver. The word "banská" in Slovak refers to "mining".

Later, German-speaking Austria dominated the Austro-Hungarian Empire and the German language became the official administrative and military language until the demise of the Empire at the end of WWI. The town of Lučenec, the administrative centre of the Novohrad or Nógrád region, became a significant military town. (Austro-Hungarian composer Franz Lehár, "the King of the operetta", was stationed here as the band master.) The Slavic-to-Magyar transliteration of this region is a good example of the original Slavic settlement in the area. "Novohrad," with its centre Lučenec, means "New-town" or "New-castle" in Slovak. The influence of the Russian language became significant during the "Russophile" era of the $19^{\text {th }}$ century and later during the post-WWII communist era.

The multifaceted diversity of all of these historical linguistic influences on the Slovak language and culture-from the prehistoric pagan Slavic and Old Slavonic, Celtic (words of Celtic origin remain in Czech and Slovak), Irish, Latin, Frank, Byzantine Greek, Magyar, German, French, Czech, Turkish, Polish, Russian and Eastern Slavic, even Roma or East-Indian-makes Slovakia, and especially the Novohrad region in the Southern Slovakia, one of the richest and most diverse of all cultural regions in Europe, and perhaps anywhere in the world.

\section{Life and Work of Timrava ${ }^{4}$}

Božena Slančíková-Timrava (1867-1951) was born as one of eleven children in the family of the Lutheran pastor Paul Slančík, a co-founder of the Slovak cultural association Matica Slovenská. Božena received an average education, yet the additional home schooling by her father made a significant difference-several of the Slančík children became well-known in Slovak cultural and literary circles.

Božena spent practically her entire life in the Novohrad region of southern Slovakia. She grew up in a village named Polichno. After her mother's death, she moved to nearby Ábelová, and retired in Lučenec. It is important to realize that Timrava's world was geographically quite small, as both villages are only a few miles away from the regional town of Lučenec, and superficially it may seem as paradoxical that a person who rarely ventured outside of her little world would be able to acquire a deep knowledge and understanding of world affairs in the complex European politics which encompassed Slovakia.

Timrava was an intelligent and shy girl, somewhat reclusive, but with an extraordinary ability to be an impartial judge of human character and its psychology. This later became a hallmark of her

\footnotetext{
4 Various sources have served to compile this biography: www.bstimrava.estranky.cz/clanky/datumy.html; www.timrava.sk/zivotopis.php; the introduction to Rudinsky's That Alluring Land, Slovak Stories by Timrava and the letters of Timrava. (Kusý, Korešpondencia Timravy a Šoltésovej).
} 
literary work. She usually sat apart during the frequent family gatherings or visits by Slovak intelligentsia, clergy and teachers, merely observing and listening, and undoubtedly thinking, trying to penetrate deeply behind each person's conversation and façade.

Her favourite place was by a mountain spring called Timrava between the two villages, where she would often seek solitude for reading and writing. She chose this as the poetic name under which she published her first works, and this name, besides her innocence and objectivity as a writer, reveals another crucial virtue, her utter "unapproachable humility" — "Bola tam taká čistučká voda hôrna ... Nechcela som, aby ma poznali [It was such pure mountain water... I didn't want to be known]" (my translation). Afterwards Božena Slančíková affectionately became known as Timrava.

Her life was simple but not uncomplicated by daily worries and her love, even agony, over the emerging Slovak nation and its language. ${ }^{5}$ Timrava later summarized this anguish in her 1926 novel All for the Nation. She wrote and published about fifty works altogether, teenage poems and songs, later short stories, novels and a few dramas.

Profound and passionate debates about nation and its language were at the heart of post-WWI Czechoslovakia and they also involved its founder and beloved president, T. G. Masaryk. Timrava wholeheartedly welcomed Masaryk during his visit in Polichno in 1930.6 Masaryk, who was partly of Slovak origin, had pointed out that the martyred Bohemian reformer John Hus, whose stature grew to mythical proportions (partly due to Masaryk's scholarship), cannot be considered the first Czech patriot- "Hus however wasn't national. (Hus wrote:) 'I love a good German better than a bad Czech..." (Masaryk 1974: 19). Paradoxically, despite his effort to elevate Hus to the status of the first Czech national hero, Masaryk also stressed the historical importance of the Slovak language: "Of highest importance, however, was Kollár's Slávy dcera (Slava's Daughter). It is no accident that our national ambitions were first expressed by a Slovak: linguistic consciousness remained purest in Slovakia." (Masaryk 1974: 19)

Timrava's literary work and her Slovak language, the culmination of this long complex historical genesis, should thus be of interest not only to ethno-linguists but also to historians, and, naturally, also to translators of the Slovak, Czech and Hungarian language whose translations would be significantly lacking without knowledge of these deep historical and cultural phenomena and

\footnotetext{
5 The first attempt to define the Slovak or the "Slavic" nation was made by the Lutheran pastor Jakub Jakubei, a Czech émigré, in his lost 1642 work Viva Gentis Slavicae Delineatio (The Authentic Description of the Slovak Nation.) Jakubei's surviving poem Lacrymae Gentis Slavonicae (Tears of the Slavonic Nation) was the first personification of Mother Slovakia weeping bitter tears over her nation's long-lasting agony. Jakubei defined Slovakia as extending from the Carpathian mountains to the rivers Danube and Tisa (Tisza), encompassing a significant portion of modern Hungary. The 1655 Catholic hymn book Cantus Catholici, which exhibits strong Czech language influence, later mentioned a "Pannonian Slovak" nation. The sympathies of many Slavic and Slovak slavophiles in the $19^{\text {th }}$ century were oriented towards Russia. 6 Timrava personally came to welcome President Masaryk with the traditional Slovak welcome of bread and salt. She was emotionally so overwhelmed that she could barely say a few words of welcome (Letter of September 11, 1930).
} 
undercurrents-Modern multi-cultural nations like Canada and the European Union would also benefit from understanding the various social and cultural interactions and resulting problems. The fear that Weltliteratur might "be annexed by imperialistic homogeneity" (Robinson 106-107) was particularly strong among Slavs who came under such dominance a number of times in their history.

Why Timrava never married still puzzles many. Having such a deep insight into the human soul, with all of its faults, imperfections and sinful proclivities - expressed in her upbringing by the Christian theological concept of sin-one can understand that it wasn't easy for Timrava as an intelligent woman of high morals standards and expectations to simply marry any man. Many male characters in her novels reveal pitiful shallowness which stands in stark contrast to the true Christian husband of the Scriptures. Nevertheless, a teenage love poem found hidden in her estate describes the first and likely only love of her life, a young dashing school teacher who was later dismissed because he drank too much and spent too much time hunting. The poem is an indication that Timrava was already able to distinguish between merely innocent passions and real vices she later attacked in her works:

$$
\begin{gathered}
\text { Even if you play cards, } \\
\text { I will not be angry, } \\
\text { You can hunt and drink wine, I don't care: } \\
\text { I will even pour for you. } \\
\text { You will be my lord, } \\
\text { To you respectfully devoted I am. } \\
\text { My heart, it's yours: } \\
\text { For you I am ready to die. (my translation) }
\end{gathered}
$$

While all her siblings married and moved away, Timrava stayed with her parents, helping to tend their household, and later taking care of her aging mother. The pay she received for her published works was meager and Timrava remained poor. The praise and admiration of many Slovaks and Czechs were her main reward. Desperately in need of income she became a companion to a hypocritical nationalistic widow and this bitter stint was described in her story "Experience" (Kusý 27-28). She also tried to get a job as a mail clerk, but was unable to complete the necessary courses because the invading Magyar Bolsheviks occupied Lučenec. Later she reluctantly became a village kindergarden teacher and she enjoyed taking care of children and teaching them.

The height of Timrava's literary output was curtailed by illness. In 1930 she was diagnosed with artherosclerosis, likely due to the stress and depression that followed her mother's death in 1923. She often complained about a debilitating "humming and hissing in her head". Bouts of selfdoubt about the purpose of her life and literature, and despair over her beloved Slovak "pigeon-like" (bolubicr) nation often overwhelmed her. She saw Slovaks as good, simple, upright and peace-loving people, but 
also ignorant, tempted by drinking, often foolishly fighting among themselves. Their submissiveness was due to their simpleness and their lack of education since on the whole Slovaks were always unduly respectful of or trusting their overlords, like gullible pigeons who come too close to the hands that baited them with morsels of bread. 6 Worse yet, the simple Slovak people who in 1919 had been lacking national self-awareness, were now quickly sliding towards nasty anti-Czech and anti-Magyar jingoism and Timrava prophetically concluded that God would punish the Slovak nation for their betrayal of Czechs in 1939.

Timrava later recovered from her condition and resumed editing her unfinished works, but WWII put an end to all her writing and dashed her hopes for a free, just and truly enlightened Slovakia. Her last work, which described the 1918 invasion of Slovakia by the Magyar communist forces of Béla Kun (Kohn), was published in 1938 and Timrava's title Záplava (Deluge) prophesied the upcoming communist deluge of Biblical proportions that would flood Europe and the rest of the world, Slovakia and Czechoslovakia being at the centre of this torrent.

Her strongest support during those years of tribulation and her greatest literary influence, was her best friend and lifelong pen pal Elena Maróthy-Šoltésová (1855-1939) whose encouraging letters Timrava cherished. Elena Maróthy-Šoltésová grew up in the village of L’uboreč, not far from Lučenec, and also remained proud of her Novohrad origins. After her marriage she moved to Turčiansky Sv. Martin (St. Martin, today Martin) which was the main centre of Slovak cultural life. Maróthy-Šoltésová became the president of Živena, the cultural and literary society for women, and the editor of the Zivena magazine-Život means 'life'; Živena was the pagan Slavic goddess of life. Šoltésová wrote novels and stories but today she is known mainly for her many articles, literary critiques and long letters to Timrava and other Slovak writers. Šoltésová encouraged Slovak women to write and publish, forming the nucleus of Slovak literary "feminism” (Rudinsky, Incipient 82).

Šoltésová considered Timrava to be the best Slovak writer and repeatedly defended Timrava's works against attacks. While many writers succumbed to the lure of writing popular moralistic or idealistic novels, or lucrative fiction, Šoltésová understood the importance of Timrava's 'life-truth' (životná pravda) expressed through historically accurate critical realism. Both Šoltésová and Timrava were disgusted by the emerging sexual and erotic literature of the 1930s in increasingly prosperous but "Americanized" Czechoslovakia. These "daughters of Lutheran pastors" were sick of the shallow fashionable pre-WWII fiction, either of the cheap 'red literature' as it was also called, or literature for

\footnotetext{
${ }^{6}$ What Timrava meant by the term "pigeon-like" is not entirely clear. She often referred to Slovaks as a "pigeon-like" people or nation but the term wasn't clear even to her best friend Šoltésová; see, for example, her letter to Timrava of October $15^{\text {th }}, 1927$. The most intriguing reference which may have offered a good explanation was an undated letter to Šoltésová likely written in August 1923. This letter, in which Timrava criticized the Slovak peasants because they didn’t see the value of their children's education, ends abruptly: "If there were a pub in every second house that they would like. Their ideal is now liquor. Corrupt are these our pigeon-like people towards books and towards...". The next page of the letter was lost.
} 
the "lumpenproletariat," which was "barking" about material poverty but was wallowing in "mud" spiritually and morally (Kusý 211). ${ }^{7}$

During the turbulent post-WWII years the Czech and Slovak nations underwent another momentous change. In 1947 the still non-communist Czechoslovak government recognized Timrava's great contribution and bestowed upon her the much-deserved title of National Artist, the highest Czecho-Slovak intellectual honor. The communist takeover of Czechoslovakia in 1948 was the final blow for many Slovaks, including the large Hungarian minority in southern Slovakia which, after WWII, had been forced to either "re-Slovakize" or leave with 50 kilos of possessions. Many of those who considered themselves Magyars were reluctant to leave all their possessions behind and did "repatriate" but they, including Timrava, viewed the symbols of the new nationalism with suspicion. The communists realized the importance of Timrava's works and, since they couldn't ignore Timrava's widespread popularity, instead shamelessly reinterpreted the meaning of her works with bold-faced lies, guilefully turning Timrava into a champion of communist social justice while using her pro-Czech sentiment to bolster their new comradeship between the Slovaks and Czechs in post-WWII communist Czechoslovakia.

\section{English Translation of Timrava's Works}

Complex works like Timrava's realistic psychological novels with snippets of poetry and songs, which ought to convey historical and cultural accuracy and which are also highly artistic, are undoubtedly the most difficult kind of literature to translate. Timrava and her works were not well known outside of Czechoslovakia and were completely absent in the English-speaking world until they were discovered by Norma Leigh Rudinsky (1928-2012), who graduated from Stanford University with a Master's degrees in English literature in 1952. In 1954 Norma Leigh married Július A. Rudinský, a professor of entomology who was born in Slovakia. Eventually the couple moved to Oregon where Rudinsky became a senior instructor of English at Oregon State University until 1996. The couple lived in Slovakia for several years between 1968 and 1977 where Július conducted scientific research. Rudinsky often visited Slovakia after her husband's death in 1980, continuing her research into the literature of Slovak women writers. She died in Oregon and was laid to rest next to her husband in Banská Štiavnica, not far from where Timrava lived. Rudinsky was interested in genealogy and traced her English origins all the way to the Magna Carta.

Rudinsky learned the Slovak language and her life-long work eventually culminated in the translation of six novels and stories of Timrava, which were published in That Alluring Land, Slovak Stories by Timrava (1992). The bulk of Rudinsky's research was published in her other book, Incipient Feminist: Women Writers in the Slovak National Revival (1991). This was originally meant to be a preamble

\footnotetext{
7 The last letters between Timrava and Šoltésová (1935-38) are quite bitter and sarcastic in this respect. Šoltésová was old, ill, loosing her eyesight and ability to write, but even in her very last letter of June $15^{\text {th }}, 1938$, she was still trying to encourage the younger Timrava to continue their fight against the corrupting literary trends in "our Americanized society."
} 
to Timrava's works but the book encompasses many important aspects of the history of Slovak literature and culture which were completely unknown in the English-speaking world. A few key points will be highlighted.

Chapter 1, "Male Apotheosis of Woman as Nation", deals with a unique aspect of Slovak and Czech literature where literary men understood the importance of women in culture, arts and literature. Lutherans Kollár, Šafárik, and Catholics like Hollý, encouraged women to get an education and be active in Czech and Slovak nation-building. There are interesting parallels in Czech literature that go beyond the scope of Rudinsky's work. ${ }^{8}$ Rudinsky's criticism that "these images were imposed on Slovak women and were only the means of inspiring men to work for the nation" (Incipient 4) is somewhat contentious. Nevertheless, this prompted Czech and Slovak women "to think of doing something themselves, not passively standing as mere inspiration for their men" (Incipient 27). These "feminists" were certainly an important help in nation-building, which is the subject of Chapter 2. The search for the epitome of femininity resulted in raising these women to the status of "national heroines" in Chapter 4. Issues of emancipation are addressed in Chapter 5, "Christian Equality of the Sexes", in "Part III: Women as Women." Here Rudinsky translated and published in full an important and insightful essay by Šoltésová, "The Need for Woman's Education especially from the Viewpoint of Morality."

Good translators are aware that no translation can be perfect and that compromises and practical accommodations must be made. Considering these difficulties, Rudinsky's translation of Timrava's works is very good and quite faithful. Her education, background and life resulted in an excellent practical linguistic and cultural experience of both languages and cultures, which was far better than that of the average well-trained translator or interpreter (Nida 110-111). All future translators should therefore be grateful for Rudinsky's dedication and her life-long effort. Rudinsky, who is resting in peace in Slovakia, has through her life and literary work become one of the Slovak people and her memory will remain forever in the Slovak collective mind as one the pioneers of Slovak to English translation. ${ }^{10}$

\section{Timrava's Unique Slovak Language}

Like most modern Slavic languages, standardized grammatical Slovak is a fairly new language, although, paradoxically, Slovak is also the most authentic Slavic language with roots in the Old Slavonic

\footnotetext{
${ }^{8}$ Starting with Magdalena Dobromila Rettigová (1785-1845) and culminating in the 1861 novel Prvni Ceškea (The First Czech Woman) by Karolina Světlá.

${ }^{9}$ Professor Anne Malena aptly pointed out after my presentation that Rudinsky's term "feminism", as she applied it to these Slovak women writers, is misleading within the context of modern feminism. The presentation gave a few hints but why Rudinsky chose to use the word would need further elaboration which is beyond the scope of this paper.

10 This critique, or rather addendum to Rudinsky's translation, is in no way intended to disparage her translation! The points of contention that I have raised or alluded to in this paper are meant strictly for instructional purposes in the hope of achieving the best possible future translations of Slovak and Czech literature into English.
} 
language. Yet, bitter controversies and profound claims remain that Slovak is a mere dialect of the Czech language and that historically Czech is superior to the other Slavic languages, as the true Slavy Dera (Daughter of the Mother of Slavdom), or the daughter of the mythological goddess mother Sláva or Glory (Eisner 175).

The unique characteristics of Slovak that today distinguish it from the rest of the Slavic languages are based on several Slovak geographical dialects. Sadly, there still remains today a certain undertone of jealousy between some speakers of these dialects. This hostility is mostly due to ignorance, historical and cultural, and a primitive understanding of patriotism. Historically Christianity was a uniting cultural force which was able to overcome this enmity. Owing to the intelligent effort of many Slovak intellectuals, including the Slovak literary heroines who had no linguistic animosity towards other Slavs and other languages, the Slovak language underwent a rather peaceful genesis and not an "evolution," certainly not a Darwinian struggle as some claim (Eisner, 118). The word "genesis" is finally replacing the dated "evolution", for example in Levý (2011). Both Timrava and Šoltésová were sympathetic towards the Czechs and Timrava explicitly called herself a 'Czechophile'. In any case, the hope of mankind lies not in a warlike struggle of cultures and languages but rather in tolerance and embracement of cultural diversity.

Slovak grammar was not standardized until the 1930s and another minor revision followed in the 1950s. Even educated editors like Šoltésová used words and sentences that are ungrammatical today (Kusý). Timrava's lack of higher education and the strong Hungarian influence resulted in her use of charmingly ungrammatical words and style, akin to her own 'dialect', which sadly is lost in Rudinsky's 'standard' translation. Translation of a standardized language is difficult enough but translation of dialect has been considered nearly impossible (Berezowski 29; Nida and Taber 163-173). With few exceptions, attempts to imitate this characteristic by using an English dialect like Scottish Highlander or Cockney would be not only futile but ridiculous, even insulting. An attempt at dialectoriented translation would require numerous explanations to address this uniqueness which sprang from various Slovak, Czech and Moravian dialects, some of which sound ridiculous or even comical to other Slovaks or Czechs.

To Timrava's dismay and displeasure, university-educated editors often rewrote and significantly altered many of her passages, adapting them to the latest language standards and grammar, perhaps changing their meaning or subtlety, and it is these edited published works that remain. Since most of Timrava's handwritten originals were lost during the turbulent WWI and WWII years, we may never know the full extent of these alterations. But a few interesting dialectical words survive, such as "nemerkovali" (Timrava 1942, 111), which means "didn't spare themselves." For those who can appreciate the charm of Timrava's original writing, with its many differences from contemporary Slovak grammar, here is an excerpt from her May 19th, 1918 letter to Šoltésová: 
Najpry co sa poslanych besednic tiča, prosim tedy len té dat ke uverejneniu ketoré ste za dobré uznali. O drubych stratených... Za to sa ale netrápte snimi, co sa aj nevinajdú nič za to. Co sa mojej práci na subeb tića, vlastne sceny v spolku aby ste mi ju dáko nevynechali ak. ju uverejnite. Co niečo ubladite (no aj to nebude mi dl’a vôli lebo je skutočnost' horšia) ale vynechat' ju to u气̌ nie. ... O opatrovatelky veci v Mùre... A jestli by šla do jeseni len sama mobla by ist... (Kusý 67)

My literal translation:

First, concerning the 'besednica' debating forum contributions, please therefore only those publish which you consider good. About other lost ones... Although don't agonize over them, if they are not found never mind. Concerning my work for the competition, regarding the fellowship scene, just don't leave it out if you publish it. Even if you smooth something (but even that wouldn't be to my liking because the reality is even worse) but leaving it out certainly not. ... Regarding the (position of) the caretaker of things at the Museum ... Even if I went until the fall only I alone could come...

I have chosen these few fragments from Timrava's letter to illustrate the importance of intimate details, requiring historical 'detective' work. Besednica was the discussion section of the Slovak paper Slonoviny, abbreviation of "Slovenské noviny" or the "Slovak Newspaper" published in Budapest, Hungary. Slon means elephant, Slonovina also means ivory or Ivory Coast and the paper's name today sounds funny, implying something elephantine and clumsy. Timrava entered her work Hrdinovia in the Živena magazine competition, and the fellowship scene refers to chapter IX where the unfaithful wife Ada Hlivická, whose husband is in the army, is shamelessly trying to seduce the protagonist Širický.

Timrava was responding to the previous letter of Šoltésová who at the time was still signing her letters with the Hungarian spelling of her name "Soltészová" - "S" in Hungarian sounds like the Slovak "ŠS") — and in which she politely but resolutely warns Timrava about her greatest grammatical weakness, her word order. Editors often corrected Timrava's grammar, presumably to maintain proper logic and the clarity of meaning but not knowing what was written in the originals it is difficult to judge whether 'Timrava's style was confusing or why exactly the editors misunderstood her, because overall Timrava's logic seems irreproachable.

The words tiča (concerning, regarding), té (those), or dáko (somehow) are excellent examples of Timrava's dialect. The word jestli (if, whether) is a Czechism which was deliberately expunged from modern Slovak. The word nevinajdu or "if (they are) not found" is an archaic composite word, likewise with the word snimi - in modern Slovak the preposition was separated "s nimi" meaning "with them." "Do jeseni" or "until the fall" is also considered a dialect today. There are numerous differences in accent as well which denotes the stress and the length of pronounced vowels but also other sounds in the words subeh (súbeh), sceny (scény), uverejnite (uverejnite), veci (veci), opatrovatelky (opatrovatel'ky) or ist (ist'). 
By 1927 Timrava's works were widely known and respected in Czechoslovakia yet she, the great Slovak writer, expressed her ultimate humility in a self-critical admission of her own ignorance of standardized grammatical Slovak. In her letter of December 1 ${ }^{\text {st }}, 1927$ to Šoltésová Timrava honestly wrote:

Recently I received an invitation to take over the editorship of the magazine Kindergargens in Slovakia. Of course I declined excusing myself due to my extreme business. The truth is that I still don't know Slovak grammar (for which I am ashamed) and I will hardly ever learn it. That would be some editor who doesn't know grammar! Really, how many errors have I made also in this letter? (Kusý 174); my translation)

While the perfect command of standardized language, and higher education or academic background, are an asset, true genius is not necessarily restricted by artificial constructs. It could be even argued that the freedom of being unfettered by such constraints will add to the creativity of the poet or writer. Robert Frost aptly pointed out that "[p]oetry and the other arts are (for me) what a country chiefly lives by" (qtd. in Robinson 25). Timrava's work is a perfect case in point. Yet, paradoxically, the charm and essence of Timrava's language and poetry simply cannot be satisfactorily translated since, as Frost also concluded, "poetry is what gets left out in translation"11 (qtd. in Robinson 25). Sadly, every translation of Timrava will thus be merely a standardized version of the original, hopefully conveying precise meaning and some of her art and poetry.

\section{Slovak Names and Diminutives in Works of Timrava}

For an author and translator, names are the most important artistic device, because they form an integral information context and they give a good clue about the essence of each character and his or her soul. Nicknames are quite common in real life but they are circumstantial and obscure. For a writer and reader, when dealing with a plethora of characters, the overuse of nicknames can be confusing. The most straightforward way to name characters is by using only their first and last names as Timrava often did.

In both Slovak and Czech the form of a person's name is indicative of the character's positive or negative role, or the speaker's or author's predisposition towards the person or character. Generally in Slovak as in other languages calling somebody by his or her first or given name, or the "Christian" name, implies friendliness, affection and familiarity. Using only one's last name or surname is a sign of unfamiliarity, indifference, or contempt. Middle (Christian) names aren't often used in public but they have a special significance to the person's immediate family such as honoring a distinguished family predecessor or a favorite saint. They also perform the social family bonding function, such as a

\footnotetext{
${ }^{11}$ Frost himself struggled with the paradox. Robinson further clarified Frost's, and every translator's, dilemma: “These two concepts, that poetry is lost in translation and that it cannot be paraphrased, are both aspects of an essential definition of poetry, one that is linguistically essential, and under the interpretation that languages are national languages" (25).
} 
mother naming her child after the father's parents or predecessors, and vice versa, expressing her or his desire to be accepted into her new husband's family.

While Russians have their unique patronymic (middle) name, Czech and Slovak names were standardized in 1786 by the Austrian emperor Joseph II as a combination of their first Christian name and their surname which originally referred to the person's family lineage or house. Rudinsky translated Timrava's renowned novel Ťapákovci as “The Ťapák Clan”, but more correctly it should be “The Ťapák Family" or the "The Tapák House" because clan means a group of associated families or houses and there were no clans in Czech and Slovak history. The number of distinguished family lineages gradually decreased and after 1786 a Czech or Slovak was free to choose a surname, thus it is more correct to talk of family over several generations rather than an old lineage of which only a few exist.

A unique feature in Slavic languages identifies a woman's surname by the suffix "-ova" or "ová" or "á". This indicates a female surname, and in Slovak and Czech it now means the "daughter or wife of", "married to", or "belongs to", implying father's or husband's family. Timrava consistently used the archaic suffix "-vie" and "-a/ a" which means "of the family or house." Rudinsky's translation uses the modern form “-ová.” So Timrava’s Anća Demákovie or Anka Matvejovie is translated by Rudinsky as Demáková and Matvejová, their family/husband's name being Demák and Matvej. The female form of the family names which end with the masculine gender "y" or "ý" are "a" or "á", like Mila Domská, her father or husband being Domský, or Liza Malinská/Malinský.

However, the issue of the translation of Slavic names is even more convoluted. Norma Leigh married into the Slovak family 'Rudinsky' (male gender), thus her last name became 'Rudinská' (female gender) in Slovak, yet 'Rudinsky', which disregards the female Slavic suffix and Slavic diacriticals, is used in English. The English form of Slavic names, especially in multi-cultural Americanized society, is not subject to strict rules. One could point out a variety of current unique forms in Czech, Slovak or Ukrainian, such as the name of my colleague who chose the suffix '-yy' in English to phonetically represent the Ukrainian '-ij' in his name, to avoid the annoying English pronunciation of ' $j$ '.

While all major languages have diminutives, Slovak and Czech rely heavily on them and also have diminutives of diminutive, (double or triple diminutives), especially in the various folk dialects. Diminutives thus give a crucial distinctive cultural character to both Slovak and Czech languages. The diminutive is closely related to the concept known as 'hypocorism' from the Greek bypokorizesthai 'to use child-talk'. It conveys affection, fondness, loving intimacy or preciousness, especially towards small and precious persons and things. The common name Ann/Anne (Anna in Slovak) has the English diminutive Annie, but in Slovak or Czech there is a variety of common diminutives or accentuated diminutives or diminutives of the diminutive - Anka, Anička, Aničička, Andulička, etc. Some names such as Elizabeth have a number of English diminutives (Betty, Liz, Lizzy, Bessie, etc.), but these are 
all equivalent diminutives, not accentuated diminutives. This concept further extends to persons and things or their description.

In Slovak frajerka (girlfriend or lover) most often has a neutral connotation, like 'Anne', and the neutrality of the context of the word frajerka is in Slovak mostly understood in the sense that the male lover doesn't really care too much about this particular girlfriend, she could be one of many. This attitude is expressed in many folk songs where a young man sings about many girlfriends he has had and about whom he doesn't really care any more. However, the diminutive frajerốcka or frajerečka generally expresses a true and only love, the precious girl about whom the lover cares or whose loss he regrets.

A similar attitude is expressed towards both the animate and inanimate objects. Ruka (hand) vs. ručickea (little hand, child's hand); kôn (horse), affectionate koník (little horse) and accentuated konícek (very little horse, meaning favorite or dearest horse); kniba (book), kni ̌ka (little or precious book), and accentuated knižočka (favorite child's or children's book); bledá (pale, feminine), accentuated bledučká (a pale little girl, or a pale and perhaps sick dear lover), and even more affectionate bledušenká or bleducičcá which defies easy and straightforward translation signifying an even greater degree of affection, such as 'my dearest and most precious pale sick little girl.' This relationship between the escalating degree of diminutives is well expressed by the word maly' (small), malinky or malinkaty' (very small), malilinký (extremely small), malilinkatý (excessively small, tiniest possible).

When translating, care ought to be taken to use an equivalent diminutive and its accentuation if possible. It will always be a challenge to translate Slovak and Czech into languages without equivalent diminutives or similar diacritics, as the translation will acquire unnatural characteristics since without accentuated diminutives the only way to facilitate the translation is by using appropriate contextual synonyms, words like 'little, small, tiny, slight, petite, brief, trifling,' etc.

Slovak also has an opposite form of the diminutive, the augmentative, indicating large size, awkwardness, unattractiveness or repulsiveness. By choosing the augmentative form Anća in her opening sentence in her novel Hrdinovia or "Heroes", (which Rudinsky translated as "The Great War Heroes"), Timrava expresses both the general characteristics and the author's attitude towards the character of Ann Demáková. Anća is a bitter and resentful widow and the reader can immediately anticipate such a character. In contrast, in the same novel Timrava called another character Anka Matvejovie, immediately suggesting a rather pleasant and good natured woman, and indeed Timrava later describes her as Matvejovie pekná Anka which is best translated as "pretty Annie Matvejovie". Although not done commonly, one could artistically extend the augmentative to other objects, with words like ručisko or konisko (a huge or ugly hand or horse). In Ťapákovci (The Ťapák Family) Timrava took the art of the augmentative to the extreme when she named her famous characer Anća-zmija (Ann the viper), indicating the utter repulsiveness of the bitter and treacherous crippled woman. 
In her novel Hrdinovia (Heroes) Timrava also chose a number of neutral colloquial names (distinct from nicknames) such as Zuza Omelkovie (Susan, from Zuqana), Liqa Malinská (Liz, Elizabeth, from German Liesl), stará Beta (old Betty), and the names of all these women indicate average unexceptional characters, not bad or evil, but neither particularly virtuous nor extraordinary. Other subtleties in the naming of characters can reveal the author's attitude. Omitting the first name and calling someone by his or her last name only, such as Pekovka or Demácka again indicates the augmentative, which can be even further augmented, as in "stará Demáckea" (old Demáková), the mother-in-law of Anča Demák.

There are, however, exceptions. Again, in Hrdinovia, "stará pani Mollerka" means "old lady Moller" but here the word lady adds dignity and thus negates the augmentative Mollerka, indicating a dignified and perhaps likable old lady. Timrava sometimes follows this naming scheme to its ultimate progression. She starts addressing the young idealistic miss Gréta (Margaret), the foster child of lady Moller, by an augmentative "そ̌aba Gréta” (frog Gréta) which Rudinsky correctly translated as "polliwog." Later Timrava uses Gréta's neutral form of her colloquial name without the augmentative "frog" and only much later, through the development of her character when Gréta's virtue and compassion is revealed as she desires to become an army nurse, Timrava changes her name to the affectionate diminutive Grétka. It may or may not be possible to translate such intricacies but without proper understanding or an explanation, the reader of the translated text may remain confused about the various names in the original or in 'standard' translation, he or she will miss a lot of such subtlety and artistry.

I have searched very hard to find and categorize diminutives in Timrava's novel Hrdinovia (Heroes) but the ones I could find, with a few exceptions, are all in the direct colloquial speech of the Slovak characters, and none in the author's voice or in her descriptions! She thus allows her characters to sing about frajerôcke a and to address each other by the diminutives of their names (Grétka, Feri for Ferdinand, or Laci for Ladislav) but she herself almost contemptuously refers to everybody either by the augmentative (frog Gréta, Demáčka), by the neutral form of their first name (Gréta, Liza) or sternly by their formal full name or surname (Širický, Balán). This clear distinction so characteristic of Timrava's style should also be followed when translating. Moreover, exceptions can be contextually significant and further context should be identified. Extra effort sometimes leads to stunning revelations of hidden meaning.

Otherwise there are no set rules for translating names and the translator will have to use her sense and intuition. Perhaps the best approach is to use an English equivalent of an ordinary name if one exists, (Betty, Liz, Susan, Annie) and preserve the character of the source by not translating some unique names like Pekovka, Duro, or Grétka. Palo could be translated as Paul, but translating Duro as George would ruin its Slovak character. In these cases a footnote could explain the unique name and its usage. Ironically, older surnames which end with "-vie" (Matvejovie) may be less of an irritant to modern feminists than the modern form "-ová" (Matvejovâ), which is the current Slovak standard. Since 
Pal'o Dubovie is a symbolic character, it is not wrong to translate his name as 'Paul Oak' or 'Pal'o the Oak'.

\section{Foreign Words}

The strong historical influence of other cultures and languages, during the Austro-Hungarian Empire era, mainly Magyar, Czech, German but also Russian, even Hebrew and Roma, had a significant impact on the purity of the Slovak language. Most Slovaks learned Magyar and many also learned German. At the level of the ordinary folk language this resulted in a curious and often comical mixture of languages, dialects and accents. As an illustration, one such funny Slovak-Hungarian phrase I remember from my childhood is Idem do vároša po orvoša (I am going to town to get a doctor), words város (town) and orvoš (doctor) being Slovakized words of Hungarian origin. Using Slovak equivalents mesto (town) and lekár (doctor) the proper Slovak phrase is Idem do mesta pre lekára.

Hungarian had a strong influence until WWII, especially in southern Slovakia where both Slovak and Magyar are still spoken, and there was a strong and understandable tendency to purge foreign words from Slovak. Nevertheless, despite the criticism of the Slovak purists who were and perhaps still are prejudiced, these words form a unique characteristic which adds to the charm of Timrava's works.

$\begin{array}{lll}\text { Timrava } & \text { Magyar/Hungarian } & \text { English/Rudinsky } \\ \text { Kišasonka } & \text { Kisasszony } & \text { Young Miss (or young lady) } \\ \text { Apo } & \text { Apu, Apa } & \text { Father } \\ \text { Báčik } & \text { Bácsi } & \text { Uncle } \\ \text { Ovoda, dadov } & \text { Óvoda, dadó } & \text { Kindergarden, nursery } \\ \text { Ovodáška, dadovka } & & \text { Kindergarden teacher } \\ \text { Nagysad } & \text { Nagyság } & \text { Your highness (character Ida) } \\ \text { Kračún, Kračunny } & \text { Karáczony } & \text { Christmas }\end{array}$

There is further contextual meaning or subtlety to most of these words. Kišasonka was used as flattery or as contempt, one could use it to flatter even an older woman. The slightly condescending bácike, a diminutive, was used to politely address any older man, especially in the era when most of the older generation was illiterate, while the younger one was educated and thus of higher social status. The communist era with its súdrub/súdružka (comrade/'comradess') equalized the social status of the worker and peasant classes, and today one would use pán/pani/slečna (Mr/Mrs/Miss). Ovoda (destká škôlka or "children's little school" today) was used because Slovak did not have a term for kindergarden as this was a Hungarian social innovation. Timrava referred to herself as ovodáška, "ška" being the Slovak suffix attached to the Hungarian word ovoda, and she may have projected herself into the character of ovodásk a Lía Malinská in the novel Hrdinovia (Heroes). The origin of some of these words, like the charming but puzzling word Kračnin, presumably of old Slavic origin from which the Magyar 
Karáczony was later derived, may not be easy to trace without other sources and cross-references and it is interesting to note that in her letters Timrava interchangeably used both Kračun and the modern Slovak Vianoce, which may have been derived from the Czech Vánoce. Nagysad doesn't sound right and it may be a spelling mistake of the original editor.

There are a few Czech-sounding words in Timrava's letters (which were not edited), indicating that some Czech words may have also been present in the lost originals of her published works. Curiously, there aren't any Czech words in the 1928 or the 1941 published editions of Hrdinovia, since by this time the Slovak was pretty much standardized and purged of all Czechisms. Until 1938 Czechs and Slovaks were on very friendly terms. Most of the Slovak intelligentsia, including Šoltésová and Timrava, (who called herself "cechofilke a" or Czechophile), were quite fond of Czechs. Slovaks had their sons educated in Prague and many ordinary Czechs and Czech intelligentsia were genuinely fond of Slovaks, like writer Karel Čapek, painter Jan Hála, and Dr. Jan Menšík who arranged the first ever publication of Timrava's books in Prague. Both in the novel Hrdinovia (Heroes) and in Záplava (Deluge) the villagers were happy when the Czech army defeated the Magyar Bolsheviks and recaptured Slovakia.

Timrava also spoke German, but admitted she couldn't carry a good conversation. A few German words can be found in her published edited works: untauglich (unfit for army), and schwach (too weak), underlining the multi-lingual nature of the Novohrad region and the Austrian military presence. Rudinsky appropriately left these words untranslated. Historically and translationally the most significant foreign word is "sklavenhändler" (slave dealer) which Rudinsky also left in German. The history of slavery, especially in the context of the Slavic women and children who were captured and sold as far as Turkey, Egypt and Africa, is beyond the scope of this paper, but one cannot fully understand the context and Timrava's subtle puns without knowing something about the history of slavery in Slavic countries. In fact, Rudinsky did indirectly translate the word because Timrava explained it a few sentences later as "slave seller" and "enslaver". This raises another important point about a meaningful translation. At what point during the expansion of the translated word is the word really fully translated and understood? Neither Timrava nor Rudinsky explained the real historical significance of sklavenhändler. Timrava assumed that the Slovak audience would know enough of its own history to understand the word and her puns. Unfortunately, the English audience, and I suspect most Slovaks and Czechs today, will be mostly left in the dark without a proper explanation.

\section{Idiomatic Nature of Language, Difficult to Translate Words, Phrases and Idioms}

Every language has words, proverbs, phrases or idioms that are intrinsic to it and deeply rooted in its culture and these are generally translatable only with great difficulty (Belloc 1931, 15; Bassnett, Translation 147; Bassnett Translation Studies 125). Idiom, in its wider sense, is what translation is all about. Belloc saw the whole political problem of Europe before and after WWI as a disunity of "no less than five major idioms" signifying the disunity of conception, script, habitual life, art, and religion. 
For Belloc, as a historian and politician, translation was a crucially important practical activity (Belloc, A Conversation 138-9). The problem of our modern world in the $21^{\text {st }}$ century is essentially the same: the faithfulness of communication and correctness of translation (Schäffner and Bassnett 233-240).

Belloc's six rules of translation were a major theoretical contribution to translation studies. His rule about "blocking out" the text corresponds to the difficulty of determining the "translation units," which is the central problem for translators. His other rules stress the importance of translating "idiom for (corresponding) idiom", "meaning for meaning" and "intention for intention" (Bassnett, Translation Studies 125-6). Thus it is the idiomatic nature of the source text, in both its wider and narrower sense, that will tax the translator's knowledge and skill, sometimes forcing him or her to simply omit intricate source text altogether for the sake of simplicity or expedience of translation, even if such omissions may be considered “immoral”, using Levý's terminology (Bassnett, Translation Studies 33).

It is precisely because translation is unidirectional that there is a determining factor when considering the suitability of translator: "Because a translation is always in some way related to the source, the translation method can be defined through that relationship in a somewhat 'unidirectional' way..." (Levý 14). Arguably, and despite Belloc's advice that "the translation should be into the language of the translator" (Belloc, On Translation 12), the best translator of exact meaning, who can best convey the fullest original sense, would rather be a native-born and native-educated person who was intimately immersed in the source culture and its history and who has subsequently acquired a good working knowledge of the target language, its culture and history. Such translation may not result in the highest degree of "Englishness" as Belloc demanded, which can be easily remedied by collaboration and editing, but such a translator will nevertheless convey more accurately the essence of the original cultural and historical meaning.

Despite her excellent credentials and professional background Rudinsky was disadvantaged, because she lacked the depth of immersion into the Slovak culture, the depth which only a nativeborn, native-raised and educated person can acquire. Indeed, there are crucial contextual errors and omissions in Rudinsky's translation which would require an in-depth analysis and cannot be included here. Several simpler examples of idiomatic problems in Timrava's novel Hrdinovia (Heroes) must suffice to highlight the problems. In the following text T denotes Timrava's original, R is Rudinsky's translation, $\mathrm{L}$ is my literal translation.

1) T: 5 kíl vyseje. L: "5 kilos will seed." In economically poor Slovakia a rich peasant would seed 5 kilograms of seed. Since Rudinsky's target audience and her own background was North American, she substituted "hundred pounds" of seed which the typical rich North American farmer would presumably seed. 
2) T: Že je okres nie plačúci? L: “That the whole region/county isn't crying?” R: omitted. This rather unique phrase or pun means that the whole county wasn't really sorry about the fact that justice was served when the rich hypocrite Balán was finally summoned to be drafted into the army (Timrava's pun; the corrupt Baláň eventually did manage to weasel out.)

3) T: Prístavok Duro, L: "Ďuro, the added one". R: omitted, translated simply as "Duro". There is no good English equivalent. Pristavat' means to add something by building, such as an additional room to a house. By prístavok. Timrava meant a male person of inferior social status who marries into a rich family or a prestigious "house". Typically a poor woman marrying into a rich peasant family wasn't desirable but it was socially tolerated and understandable that a rich peasant or a 'blue-blooded' young man might choose a good-looking girl from a poor family. The word prístavok stresses the rarity or irony of this particular marriage.

4): T: Pulsy, L: "Pulses." R: "Pauses." Ringing of church bells was an integral part of Slovak Christian culture and it was once considered an art. Rudinsky's translation is correct, yet the modern reader will be baffled despite the given context. 'Pauses' refers to the specific way in which church bells were made to ring to express grief by adding pulses or periods of calm that would disrupt the periodic rhythm of church bells ringing.

5) T: Krstit' vino, L: “To baptize wine”, R: "Drinking wine." This is either Rudinsky's error or her deliberate omission in order to avoid the thorny context. Timrava's pun means "to dilute wine" or to be dishonest. There is a deeper religious and cultural context: Jesus' first miracle of wine at Cana, and profound Catholic theological significance of mixing wine and water during the Mass. It was the Jewish innkeeper who was cheating his Christian customers by "baptizing" wine, beer and liquor.

6) T: Žial', sud sa obláša. L: "It's a pity, barrel is announcing itself." R: "Barrel is echoing." Using the word "echoing" is not a bad translation but the original oblása adds charm, since it adds anthropomorphism, as if the wine barrel were alive and talking, not merely echoing back when tapped, indicating there isn't much wine left. "It's a pity", which Rudinsky omitted, indicates this was a barrel of good wine.

\section{Conclusion}

Renowned Czech translator Pavel Eisner saw the trends of globalization and worried about the fate of his beloved Czech language. The great languages, originally the languages of conquerors, have always had an advantage over the languages of conquered nations (Eisner 583). The emerging Slovak intelligentsia, exemplified by Timrava as perhaps the greatest of all Slovak writers, also worried about the life or death of their beloved mother-tongue, and thus of their nation and culture which briefly sprang to life after a millennium-long impasse. In our emerging post-national and transcultural world this 'angst' of small nations has not disappeared, arguably it has increased, as even the national identities of bigger nations (French, German, Spanish) are being quickly eroded in our era of English 
language dominated Internet, business, science, technology and communications (Schäffner 3, Schäffner and Bassnett 157).

As much as all smaller nations desperately try to preserve their language and culture, good translation seems to be the best conceivable solution to this perennial dilemma. The new cultural paradigms are today created by the Fremdbild which is the way a person of a different minority language and culture is seen by other people of the dominant culture (Schäffner 29). Faithful and accurate translation can correct the falsely created Fremdbild, a pseudo-vision of a national minority created by shallow uninformed opinion based on superficial or falsified history. Unfortunately, the current model of publishing in the emerging trans-national literature does not favor translation but Venuti's "utopian ideal" of establishing a "culture of translation" and making translators more prominent is certainly worth pursuing (Bassnett, Translation 175).

The current over-domination of English should not be seen as a mere cultural conquest, despite alarming statistical trends (Bassnett, Translation 23), but rather as a fair democratic chance which can allow smaller nations and their languages a niche in the emerging Global village and which will somehow bring the historical meaning of each nation its due and hopefully result in its fullest blossoming and fruition. How this can happen remains to be explored.

As incomplete as my paper is, it is my hope that it has at least stressed the importance of correct and meaningful translation by focusing on the true essence of translation, because it is the knowledge of the "textual grids", "cultural grids" or "cultural capital", which will influence "how reality is constructed both in source and target texts," and it is "the skill of the translator in manipulating these grids [which] will determine the success of the outcome” (Bassnett, Translation Studies 9). 


\section{REFERENCES:}

Bassnett, Susan. Translation. The New Critical Idiom series. Routledge, London and New York, 2014. . Translation Studies. Fourth edition. Routledge, London and New York, 2014.

Belloc, Hilaire. A Conversation with an Angel and Other Essays. Jonathan Cape, London, 1928.

—. On Translation. The Taylorian Lecture. Oxford, Clarendon Press, 1931.

Berezowski, Leszek. Dialect in Translation. Wrocław, Poland: Wydawnictwo Uniwersytetu Wrocławskiego, 1997.

Čapek, Karel. In Praise of Newspapers and Other Essays on the Margin of Literature. Essay in Praise of the Czech language. Trans. M. and R. Weatherhall. London: George Allen \& Unwin Ltd, 1951.

Dawson, Christopher. The Dynamics of World History. London: Sheed and Ward, 1957.

Eisner, Pavel. Chrám i Turz, Kniha o Češtine, I. díl [Cathedral and Fortress, Book about Czech Language, Part I and II]. Zürich: Konfrontation, Verlag, 1974.

Hála, Peter. "Sailing to Byzantium, The life and Mission of Saints Cyril and Methodius. Part I." Catholic Insight 21.10 (2013) 18-23.

- "Sailing to Byzantium, The life and Mission of Saints Cyril and Methodius. Part II." Catholic Insight 22.10 (2013) 17-22.

Kusý, Ivan. Korešpondencia Timravy a Šoltésovej [Correspondence of Timrava and Šoltésová]. Ed. Ivan Kusý. Bratislava: Nakl. Slov. Akadémia Vied a Umení, 1952.

Levý, Jiří. The Art of Translation. Trans. Patrick Corness. Amsterdam/Philadelphia: John Benjamins Publishing Co., 2011.

Masaryk, Tomáš, G. The Meaning of Cz̨ech History. Trans. Peter Kussi. Chapel Hill, NC: The University of North Carolina Press, 1974.

Nida, Eugene A. Language, Culture and Translating. Shanghai: Foreign Language Education Press, 1997. and Charles R. Taber. The Theory and Practice of Translation. Leiden, the Netherlands: United Bible Societies, E. J. Brill, 1982. 
Robinson, Peter. Poetry and Translation. The Art of the Impossible. Liverpool: Liverpool University Press, 2010.

Rudinsky, Norma, L. Incipient Feminist: Women Writers in the Slovak National Revival. Columbus, Ohio: Slavica Publishers, 1991.

- That Alluring Land, Slovak Stories by Timrava. Pittsburgh, PA: University of Pittsburgh Press, 1992.

Schäffner, Christina. Translation in the Global Village. Clevedon, UK: Multilingual Matters Ltd, 2000. and Susan Bassnett. Political Discourse, Media and Translation. Newcastle upon Tyne: Cambridge Scholars Publishing, 2010.

Timrava, Slančíková Božena. Timrava: Hrdinovia. Mazáčova Slovenská Knižnica, Sväzok IX. Prahe: Nakladatel' L. Mazáč v, 1928.

- Hrdinovia, V Čas Vojny, Záplava. Ed. Dr. Stanislav Mečiar. Sobrané Spisy Timravy, Sväzok X. Redigoval Dr. Stanislav Mečiar. Vydala Matica Slovenská, tlačila Neografia. T. Sv. Martin, 1942. 